\title{
Alleviating Global Poverty: Labor Mobility, Direct Assistance, and Economic Growth
}

\section{Lant Pritchett}

\begin{abstract}
Decades of programmatic experimentation by development NGOs combined with the latest empirical techniques for estimating program impact have shown that a well-designed, wellimplemented, multi-faceted intervention can in fact have an apparently sustained impact on the incomes of the poor (Banerjee et al 2015). The magnitude of the income gains of the "best you can do" via direct interventions to raise the income of the poor in situ is about 40 times smaller than the income gain from allowing people from those same poor countries to work in a high productivity country like the USA. Simply allowing more labor mobility holds vastly more promise for reducing poverty than anything else on the development agenda. That said, the magnitude of the gains from large growth accelerations (and losses from large decelerations) are also many-fold larger than the potential gains from directed individual interventions and the poverty reduction gains from large, extended periods of rapid growth are larger than from targeted interventions and also hold promise (and have delivered) for reducing global poverty.
\end{abstract}




\section{Alleviating Global Poverty: Labor Mobility, Direct Assistance, and Economic Growth}

Lant Pritchett

Harvard Kennedy School and Center for Global Development

This is based on a speech presented on November 27, 2017 as part of the 2017-2018 lecture series, "A 21st Century Immigration Policy for the West," co-sponsored by Reason Foundation and Michigan State University's Symposium on Science, Reason and Modern Democracy. It will appear in a forthcoming volume.

Lant Pritchett, 2018. "Alleviating Global Poverty: Labor Mobility, Direct Assistance, and Economic Growth." CGD Working Paper 479. Washington, DC: Center for Global Development. https://www.cgdev.org/publication/alleviating-global-poverty-labormobility-direct-assistance-and-economic-growth

Center for Global Development 2055 L Street NW Washington, DC 20036

202.416 .4000

(f) 202.416 .4050

www.cgdev.org
The Center for Global Development is an independent, nonprofit policy research organization dedicated to reducing global poverty and inequality and to making globalization work for the poor. Use and dissemination of this Working Paper is encouraged; however, reproduced copies may not be used for commercial purposes. Further usage is permitted under the terms of the Creative Commons License.

The views expressed in CGD Working Papers are those of the authors and should not be attributed to the board of directors, funders of the Center for Global Development, or the authors' respective organizations. 


\section{Contents}

I) The least you can do is better than the best you can do ..................................................... 1

I.A) What are the gains to incremental low/moderate skill labor mobility?...................... 2

I.B) What is the "best you can do" to increase individual incomes in place?..................... 6

II) The place premium and "A" (Total Factor Productivity) .................................................... 14

III) "Foreign aid" and its impact versus immigration ...........................................................17

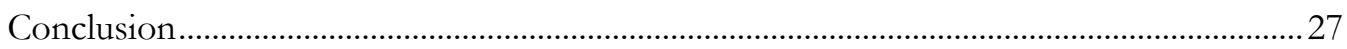

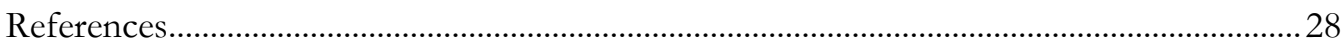


I am going to start with a simple but striking claim, defend that claim, and then circle back to the broader questions the title raises. My simple claim is that as any citizen of the West contemplates the question "What could we do to alleviate global poverty?" the right answer is: "The least you can do is better than the best you can do." Let me back up that pretty astounding and seemingly contradictory claim, then come back to the broader question of the efficacy of "foreign aid" as either (a) direct assistance to targeted groups or (b) as a mechanism for promoting broad based development.

\section{I) The least you can do is better than the best you can do}

What I mean by "the best you can do" is addressing "global poverty" in the ways that individuals who want to give philanthropy directly to "the poor" ${ }^{1}$ seek. That is, what could I give money for that would fund concrete support and assistance to individuals that would produce the best outcome in alleviating "global poverty." This is the "best you can do" if you want to fund actions that directly help people in a given place. It turns out the "best you can do" to improve people's self-assessed well-being is roughly give cash. That is, one might have supposed there were investments or programs for the poor that have super-high economic returns, but, after decades and decades of search, there is very little empirical support for that idea. As we will see there are some programs that do modestly better than cash, but not many and not by that much.

What I mean by the "least you can do" is just let individuals engage in perfectly ordinary economic transactions of taking a job and getting paid a wage. The only trick is that countries in the West would have to lower their enormously high legal barriers to the mobility of low skill labor across national borders for that to happen. But this is still "the least you can do" because this labor mobility is "win-win" in the usual sense of economists (potential Pareto improving, which may take transfers to acheive). Because the people who move make higher wages because they are more productive in the Western country than in their home country total output goes up sufficiently to make everyone better off (in principle).

So think of two ways to help the global poor. One is for rich people (in a global sense) to give a dollar and get roughly a dollar's worth of benefits for the poor. The other people is for rich people to allow people who would like to work at the prevailing wage of their

\footnotetext{
${ }^{1}$ I put "the poor" in scare quotes as I argue that, given the empirically demonstrated volatility of income/consumption over time and the general dynamics of households that poverty (in the usual sense of people below a given thresholds of income/consumption) is typically a condition - a transitory state - not a characteristic - a more or less permanent feature of households (e.g. Pritchett, Suryahadi and Sumarto 2000, Narayan, Pritchett and Kapor 2009 That is, while at any given time one can say "X percent (or N number) of people are poor" by some threshold poverty line, this group does not constitute in any useful way a category called "the poor." An analogy is that we could measure on any given day the number of people with a cold but we would not therefore talk about a category of people called the "the colds" as, even if the number with a cold will remain roughly constant when measured a month later, the individuals in the category will mostly be entirely different. Ravallion and Jalan (1998) show that in rural China there is sufficient mobility between poverty and non-poverty conditions for the same household over time that using current consumption to target transfers little better at targeting "the poor" five years ahead than just a uniform transfer to all households.
} 
country to do so and not deploy active coercion to prevent this-which reflects the person's contribution to product and hence is (or can be made to be) zero net cost to the host country. Of course, a dollar for a poor person could produce vastly more human well-being than had the richer person spent the money as the marginal utility was much, much higher for the poor person, but this redistribution effect is the same for both options. This means, at least in current conditions, the least you can do-just increasing the freedom of people who want to work and people who want those people to work to carry out that mutually beneficially transaction across national borders-is better than the best you can do of trying to directly help people in poverty but without allowing them to move to opportunity.

Let me document that this is true, then explain why it is true (section II), then get back to what this implies about "foreign aid" and why some types of investments through foreign assistance might have equally high returns as labor mobility (section III).

\section{I.A) What are the gains to incremental low/moderate skill labor mobility?}

Suppose the restrictive, coercively enforced, legal barriers to a worker moving from Haiti or Nepal or Ethiopia or India or Honduras to the USA were relaxed, how much more would exactly the same worker make in the USA versus in their home country?

This is the kind of counter-factual question economists try and answer all the time about border barriers to trade and is called the price or ad valorem tariff equivalent of a non-price border based restriction. For instance, the USA has historically limited the imports of sugar to a certain quota amount and allocates that quota across countries. This means that trade will not equalize prices and that the domestic price of sugar in the USA will be higher than the price at which people in sugar producing countries are willing to sell sugar to the USA (e.g. their domestic cost plus transport costs or the price of selling to a different, non-quota, country). For any given quota of sugar imports we can ask "what is the tariff on imported sugar such that, at that price, the US domestic demand for sugar would be exactly the quota amount?" That is the "tariff equivalent" of the quantity based border based barrier to trade. In 1990 there were official USA government estimates of the tariff equivalent of sugar quotas $^{2}$ for the late 1980s. The result was that in 1987 the "world price" of sugar (landed in the USA) was 18.5 cents/kilogram ( $14.8 \mathrm{c} / \mathrm{k}$ was the price in a Caribbean port and $3.7 \mathrm{c} / \mathrm{k}$ to ship it to the USA) and the US domestic price was 48.1 cents/kilogram and hence the price equivalent of the quota was 29.6 cents/kilogram or an ad valorem tariff equivalent of 160 percent. This also creates an estimate of the "quota rent"- the gain to a sugar producer of being allocated some of the existing quota. Suppose you were the Dominican Republic and could produce sugar in 1987 for 10 cents/kilogram at your port. If could sell it on the world

\footnotetext{
2 ESTIMATED TARIFF EQUIVALENTS OF U.S. QUOTAS ON AGRICULTURAL IMPORTS AND ANALYSIS OF COMPETITIVE . CONDITIONS IN U.S. AND FOREIGN MARKETS FOR SUGAR, MEAT, PEANUTS, COTTON, AND DAIRY PRODUCTS Report to the President on Investigation No. 332 281 Under Section 332 (g) of the Tariff Act. • of 1930, as amended. USITC Publication 2276. April 1990.
} 
market for 14.8 for a landed price of 14.8 cents versus the US price less freight of $44.4 \mathrm{c} / \mathrm{k}$ you would be massively better off selling to the USA than to the world market or using it at home).

Together with some co-authors (Michael Clemens and Claudio Montenegro) we estimated the "tariff equivalent" of the US restrictions on low skill labor mobility and hence the "quota rent"- the gain to the average worker from a given country of having that quota relaxed and being allowed to work in the USA (Clemens, Montenegro and Pritchett 2008, 2016).

The first step is estimate the real wages of "observationally equivalent" workers by using the US Census and labor force surveys from 41 different countries. We compare consumption real wages adjusting fully for the purchasing power differences and hence allowing for the fact there are lower prices in poor countries. ${ }^{3}$ Using our combined data sets we can estimate the average wage for a worker with any given observed characteristics: say, a 35 five year old male, with less than high school complete, working in the urban formal sector and compare a person born Peru, educated in Peru and working in Peru to a person born in Peru, educated in Peru and working in the USA.

The second step is to adjust that raw "observationally equivalent" wage for the fact that people who move across national borders are not a random sample but are self-selected and hence it is possible that the wages of those in the USA might have been higher than their "observationally equivalent" compatriots and so that is not the right counter-factual. We use a method (the Altonji/Oster procedure) to adjust for selectivity and create upper bound estimates of the counter-factual wages of those who are in the USA had they remained in their home country. The comparison of the actual wage in the USA with the selectivity adjusted home wage produces a lower bound estimate of the gains from mobility. The results are that our worker with the specific characteristics from Peru would make $\$ 5,012$ working in Peru (note this is not the actual average across observational equivalent workers, but an upper bound adjusting for migration selectivity) but $\$ 20,579$ in the USA. Hence a lower bound of the estimated gain for a Peruvian worker with these characteristics of moving to the USA is $\$ 15,567$ per year.

Table 1 shows the results for the 10 largest countries in our study (which cumulatively have 1.1 billion population aged 15-49) and the population weighted average for all 42 countries (with total population of 1.45 billion of those aged 15-49). The average gain for the ten largest is US\$15,981 and for all 42 countries the population weighted gain is US $\$ 17,115$ per worker. This gain is because the wages of workers with these specific, low skill, characteristics increases from an annual average of US $\$ 4,740$ to US $\$ 21,855$. The same lowskill worker sees his (in this case) wage increase by a multiple of 4.6 or an increase of 361 percent on average by moving to the USA.

\footnotetext{
${ }^{3}$ This substantially understates the gains of labor mobility if workers remit or save and hence spend their foreign earnings in their home countries where prices are only a third to a fourth as high as in high income countries. So if half of earnings are saved or remitted our reported gains are far too low.
} 
Assuming that workers are working 40 hours/week*52 weeks/year=2080 hours/year this annual gain implies a "price equivalent" of the border barriers to labor mobility for workers of these characteristics of $\$ 8.23$ dollars per hour (from $\$ 2.28$ to $\$ 10.51$ ). This is an "ad valorem tariff equivalent" of the border barriers to labor of 361 percent. (Just for comparison, the average tariff on industrial goods in the USA is around 2 percent.)

Table 1: The income gains from allowing an additional low skill worker to move to the USA from various countries are between $\$ 10,000$ and $\$ 20,000$ a year (in purchasing power dollars)

\begin{tabular}{|c|c|c|c|c|}
\hline Country & $\begin{array}{l}\text { Annual income of low } \\
\text { skill worker from } \\
\text { country, educated in the } \\
\text { country, working in the } \\
\text { US, } \$ / \text { hour in } 2000\end{array}$ & $\begin{array}{l}\text { Upper bound estimate } \\
\text { of the annual wage in } \\
\text { home country, \$/hour } \\
\text { (adjusted for PPP) of the } \\
\text { same worker }\end{array}$ & $\begin{array}{l}\text { "Price equivalent" of } \\
\text { border barriers-gain } \\
\text { from labor mobility for a } \\
\text { specified low skill } \\
\text { worker }\end{array}$ & $\begin{array}{l}\text { Pop'1 } \\
\text { aged 15- } \\
49, \text { in } \\
\text { millions }\end{array}$ \\
\hline India & $\$ 23,846$ & $\$ 4,021$ & $\$ 19,825$ & 545 \\
\hline Indonesia & $\$ 21,194$ & $\$ 3,423$ & $\$ 17,771$ & 117 \\
\hline Brazil & $\$ 23,818$ & $\$ 7,005$ & $\$ 16,813$ & 97 \\
\hline Bangladesh & $\$ 19,315$ & $\$ 3,804$ & $\$ 15,510$ & 67 \\
\hline Pakistan & $\$ 21,662$ & $\$ 3,705$ & $\$ 17,957$ & 65 \\
\hline Nigeria & $\$ 18,689$ & $\$ 1,186$ & $\$ 17,503$ & 57 \\
\hline Mexico & $\$ 17,511$ & $\$ 6,849$ & $\$ 10,662$ & 54 \\
\hline Vietnam & $\$ 19,820$ & $\$ 2,624$ & $\$ 17,196$ & 44 \\
\hline Philippines & $\$ 18,133$ & $\$ 5,218$ & $\$ 12,915$ & 40 \\
\hline Thailand & $\$ 18,205$ & $\$ 7,598$ & $\$ 10,607$ & 36 \\
\hline Egypt & $\$ 20,739$ & $\$ 1,712$ & $\$ 19,028$ & 34 \\
\hline $\begin{array}{l}10 \text { largest population } \\
\text { countries average } \\
\text { (total population) }\end{array}$ & $\$ 20,266$ & $\$ 4,286$ & $\$ 15,981$ & 1,156 \\
\hline $\begin{array}{l}\text { Population weighted } \\
\text { average, } 40 \text { countries } \\
\text { (total) }\end{array}$ & $\$ 21,855$ & $\$ 4,740$ & $\$ 17,115$ & 1,435 \\
\hline $\begin{array}{l}\text { Wages per hour } \\
\text { (assuming } 2080 \text { hours } \\
\text { per year) }\end{array}$ & $\$ 10.51$ & $\$ 2.28$ & $\$ 8.23$ & \\
\hline
\end{tabular}

Source: Author's calculations from results in Clemens, Montenegro and Pritchett 2016.

While there is a fair amount of technical sophistication that goes into the calculations above, roughly the same results emerge from simpler calculations. A wide variety of methods of comparing wage differentials for workers of identical intrinsic productivity will arrive at roughly the same wage gains. For instance, Oostendorp (2012) provides a database of wages 
for various occupations around the world. Using occupations is a different approach of comparing workers of the same intrinsic productivity by comparing workers performing similar tasks. If one just takes "waiters" and compares real (PPP) adjusted wages of the top 10 wage countries to the bottom 30 countries (of those reporting, the data coverage in those dataset is far from complete) the annualized wage gap is $\$ 14,914$. For the collection of occupations in "construction" the wage gap is $\$ 25,465$. Our "low skill" number of $\$ 17,115$ between the USA and 42 countries is hence between "waiters" and "construction workers" between the bottom 30 wage countries and the top 10 wage countries (and much closer to "waiters").

Table 2: Earnings (PPP) for identical low to medium skill occupations are different between poor (bottom 30 ) and rich (top 10 ) countries by $\$ 15,000$ (waiters) to $\$ 25,000$ (construction workers)

\begin{tabular}{|c|c|c|c|c|}
\hline & \multicolumn{2}{|c|}{ Waiters } & \multicolumn{2}{|c|}{ Construction workers } \\
\hline & $\begin{array}{l}\text { Median of } \\
\text { bottom } 10 \\
\text { countries }\end{array}$ & $\begin{array}{l}\text { Median of } \\
\text { bottom } 30 \\
\text { countries }\end{array}$ & $\begin{array}{l}\text { Median of the } \\
\text { bottom } 10 \\
\text { countries }\end{array}$ & $\begin{array}{l}\text { Median of the } \\
\text { bottom } 30 \\
\text { countries }\end{array}$ \\
\hline Wages (in the latest available year) & $\$ 0.74$ & $\$ 1.46$ & $\$ 1.37$ & $\$ 2.21$ \\
\hline Wages USA ${ }^{a}$ & $\$ 7.92$ & $\$ 7.76$ & $\$ 20.28$ & $\$ 19.12$ \\
\hline $\begin{array}{l}\text { Annualized gap (hourly wage } \\
\text { gap*2080 hours/year) }\end{array}$ & $\$ 14,930$ & $\$ 13,111$ & $\$ 39,330$ & $\$ 35,177$ \\
\hline $\begin{array}{l}\text { Median wages of top } 10 \text { countries } \\
\text { (latest year) }\end{array}$ & $\$ 8.63$ & $\$ 8.63$ & $\$ 14.45$ & $\$ 14.45$ \\
\hline $\begin{array}{l}\text { Annualized gap with median of top } \\
10 \text { countries }\end{array}$ & $\$ 16,401$ & $\$ 14,914$ & $\$ 27,217$ & $\$ 25,465$ \\
\hline
\end{tabular}

Source: Pritchett and Smith (2016), using data from Ostencoop 2013.

a The wages for the USA are matched to the latest available year for each country to calculate the gap in that year and hence the USA wages are slightly different depending on the sample.

It is worth noting that the gains of around US $\$ 15,000$ in PPP are for very low skill/schooling workers. If one takes the standard results of empirically estimated Mincer regressions that wages increase about 10 percent with each year of schooling (e.g. Montenegro and Patrinos 2013) — and that this return do not decline too sharply across income levels of countries - then the wage gains from labor mobility are much larger in absolute terms at higher levels of skill/schooling and hence this estimate for just the low skilled understates the average gains from actual migration which would involve people at a mix of skill levels. 


\section{I.B) What is the "best you can do" to increase individual incomes in place?}

Suppose you had an action — a program or project — that could help poor people by raising their incomes by 10 percent for the rest of their working lives. How much would that increase incomes and how much would it be worth in net present value? The household income (consumption) of a family of four at the latest (inflation adjusted) World Bank low poverty line of $\$ 1.90$ a day would be $\$ 2,774$ ( $=\$ 1.90$ per day*365 days/year*4 people). If we suppose for simplicity this is only one earner a 10 percent wage gain for someone with a family at the global low bar poverty line is $\$ 277$ per year. (A 10 percent gain for the typical low skill worker in our sample is $\$ 474$ per year as our wages were for urban, formal sector workers, which are much higher than those at the poverty line).

An obvious but important point is that because incomes start from a low base, modest percentage increases are necessarily small absolute numbers whereas moving from a low wage place to high wage place changes incomes by factor multiples. So the annual gain from a development program/project that increased the income a low skill worker by 10 percent, $\$ 277$, is only one sixtieth of the annual gain from moving to the USA and working at the low skill wage. The annual gain from a 10 percent wage increase of the poor is equal to less than the gain from one week's additional earnings at the average low skill wage differential of $\$ 8.23$ (40 hours $* 8.23$ additional earnings per hour $=\$ 329$ in additional earnings).

Figure 1: The gains from labor mobility far exceed the gains from a 10 percent gain

Population weighted average gain from low skill labor mobility (lower bound, adjusted for migrant selectivity) for one year 10 percent increase over the Global Poverty Line

NPV of gain sustained for 50 years, discounted at 5 percent NPV, 10 percent
10 percent increase over average low skill wage

NPV of wage gain sustained for 50 years, discounted at 5 percent

NPV of 10 percent gain sustained for 50 years discounted at 10 percent

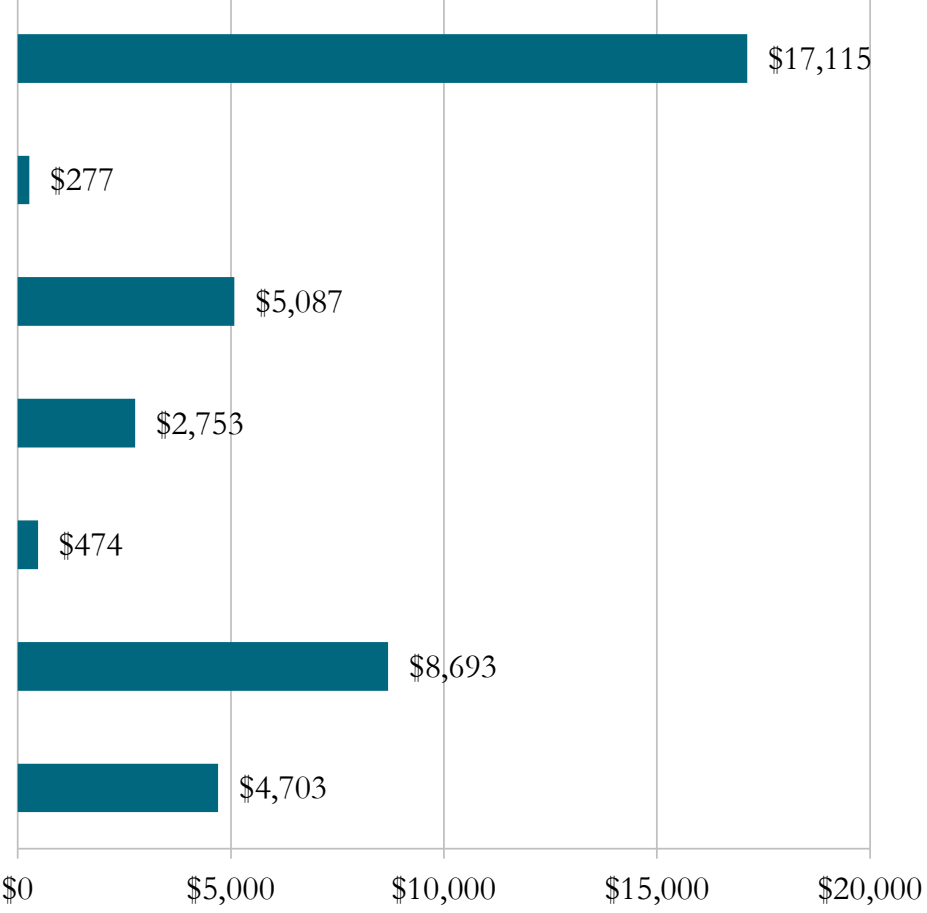

Source: Author's calculations. 
Now suppose I could do some action and this action increased the person's income (at constant effort) by 10 percent for the next 50 years. How much would that be worth in discounted net present value (discounted to take into account that future gains are worth less than present gains)? Discounted at 5 percent the total lifetime gain of 10 percent for a young worker supporting a household at the poverty line would be (about) $\$ 5,000$. This is still far less than the annual gain from one year of work in a rich country. This means if I moved to a rich country, worked for one year, saved half of the gain, and I could invest that at 5 percent and I just consumed the interest then I would produce a higher lifetime income stream from that than from something that would increase my lifetime wage income by 10 percent.

But the implication of an NPV of $\$ 5,000$ is even more interesting, as it should provide us with a rough and ready guide to how much we should expect it to cost to increase someone's income by that much. That is, people all around the world, including (perhaps especially) poor people, are anxious to improve their own material well-being and take advantage of opportunities to do so. So, suppose there was some action that could increase the income of a household at the poverty line by $\$ 277$ (10 percent) in a sustained way and it were free. Then they (or at least most or nearly all of them) would do it themselves, without any help. Now suppose (counter-factually) households could borrow at 5 percent interest and pay it back over 50 years, how much could they borrow to buy an annuity today that paid $\$ 277$ a year and be just indifferent? Well, about $\$ 5,000$. Everything worth doing is in between those two costs (free and costing exactly the NPV) so if I could invest, say, $\$ 1,000$ today to make $\$ 277$ in perpetuity I would do it in a heartbeat as the rate of return is fantastic (28 percent). ${ }^{4}$

I am just using the economist's typical arbitrage or "no hundred bills on the sidewalk" reasoning to ask what we would expect the cost of increasing the incomes of the poor through direct individual effort to be. After all, if there were a cheap and easy way for people to not be poor, and people themselves wanted not to be poor, then a plausible model of behavior would suggest that they would do this thing by and for themselves. ${ }^{5}$

Empirically, their own initiative is how most people report escaping poverty. As part of a massive exercise of participatory assessment of how people's well being had changed over a 10 year period we held village meetings in 14 countries and three states of India (Narayan, Pritchett, Kapor 2009). In a ranking exercise people ranked the level of living of households today and their level 10 years ago. This identified almost 4000 people who, by their village neighbor's assessments, had moved out of poverty. We then interviewed them and asked them what they thought the primary reason for their move out of poverty was. This is of course subject to all the subjectivity biases about how people narrate the story of their lives but 87.7 percent of them reported their own initiative (60.1 percent an initiative outside of

\footnotetext{
${ }^{4}$ These are all of course just circular calculations as the "internal rate of return" is just defined as the IRR that makes the NPV zero so the IRR of a stream of 5,000 up front today for $\$ 277$ for the next fifty years is 5 percent. ${ }^{5}$ Of course actual human behavior differs from the optimizing behavior in many ways and for many reasons from decision heuristics in conditions of uncertainty (a la Kahneman and Tversky) or large effects on decisions from "framing" of default options. Mani et al (2013) show that poverty and the stress that accompanies poverty can impair cognitive function that leads to worse choices. Also, uncertainty and risk can lead people near subsistence to under-invest in profitable actions which require learning costs (e.g. Bryan et al 2014).
} 
agriculture, 17.4 percent in agriculture, 4.7 percent accumulation of assets, and 5.5 percent hard work). Only .3 percent (12 people of 3,991) who moved out of poverty named NGO assistance as the cause.

Figure 2: People who have moved out of poverty overwhelmingly report it was their own initiative that was the primary reason for the change

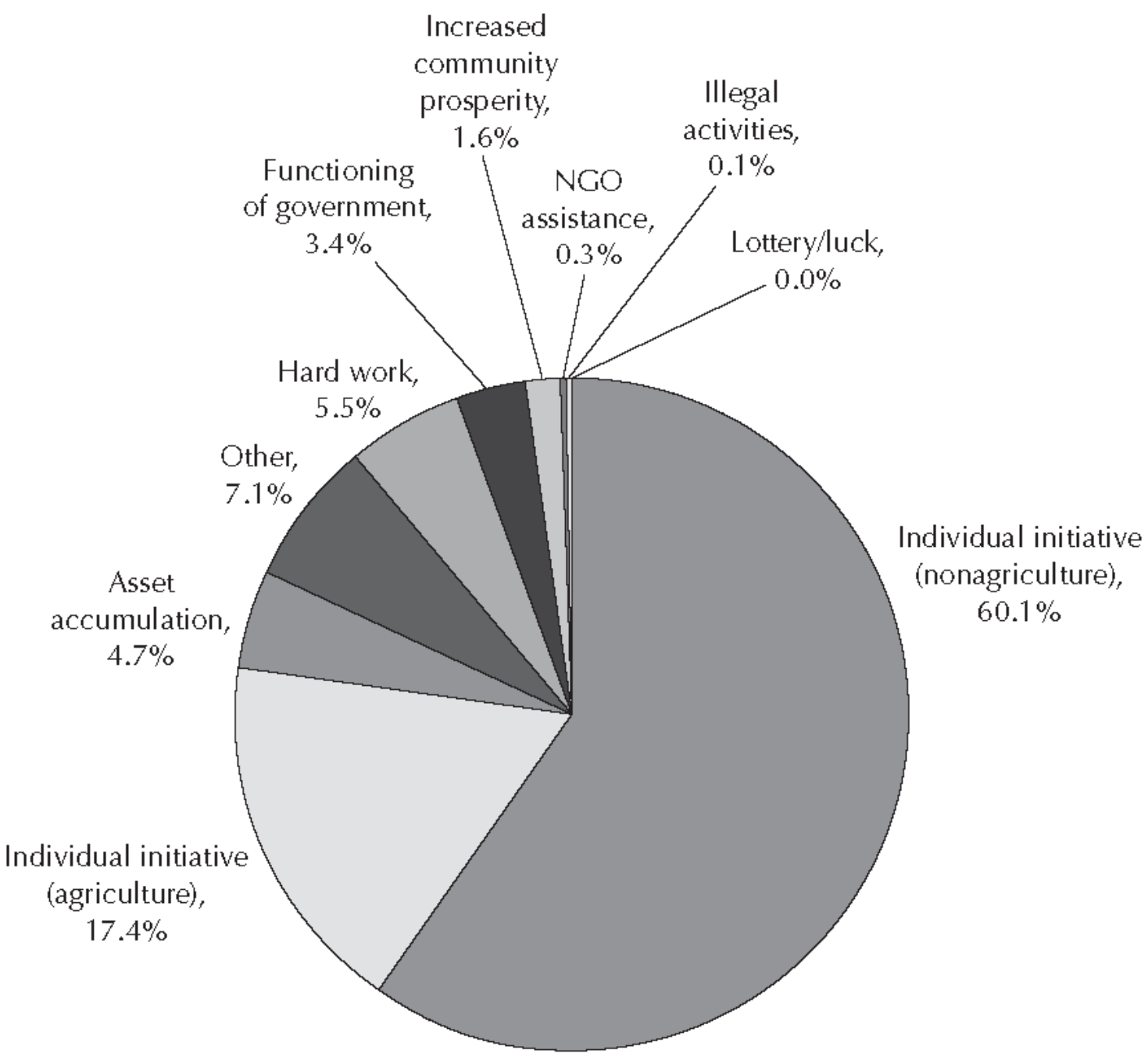

Source: Narayan, Kapoor and Pritchett 2009, based on N=3991 people moving out of poverty.

The upshot of this reasoning is that if I were asked what I expected it would cost to produce any given gain in income in situ I would guess something near the NPV of the gain at a moderately high discount rate, like 10 percent. This is not a theorem or a dogma or an assertion that everyone, everywhere and always, optimizes or that markets everywhere and always work, but rather a rough and ready appreciation that nearly all people who are experiencing the condition of poverty around the world are agents who act for themselves, often much more shrewdly and wisely than those that given them "advice." 
And the modesty that comes from a the realization that people are agents of their own destiny extends not just to savings and economic decisions and the accumulation of assets but also to efforts to provide "information" or "business training" or whatever a project or program can do. That is, if I said I could increase the sustained earnings of businesses by 10 percent at by providing them training at a cost that was low enough this was financially attractive, it is a perfectly reasonable question for you to ask why I (or someone else) are not already making money selling that training. The market for instruction and training is thick and vibrant around the world and people do make fortunes selling information and training and advice.

Having grounded our intuition a bit, let me turn to recent empirical evidence about the costs and impact of the "the best you can do" for people who are poor via programmatic interventions. Let me start with the "graduation" approach.

"The Ultra Poor Graduation program is designed to graduate ultra poor households out of extreme poverty to a more stable state. This 24 -month program provides beneficiaries with a holistic set of services including: livelihood trainings, productive asset transfers, consumption support, savings plans, and healthcare." (https://www.poverty-action.org/program-area/social-protection/ultra-poor)

This "graduation" approach is implemented and has been adopted by a number of NGOs (it is an outgrowth of BRAC's Targeting the Ultra Poor) and agencies and has been the subject of a multi-country RCT evaluation recently reported in Science magazine (Banerjee, et al 2015). Nothing I say in this paper is a criticism of this program, for purpose of my argument I am taking for granted that this is, in fact, "the best you can do" as a targeted intervention to raise the incomes of poor (or ultra-poor) households. I am not setting up a straw man of a program that failed or has not been rigorously evaluated but the opposite a program that is being widely trumpeted as cost effective and I am taking those claims at face value.

Figure 3 uses results taken mostly straight from the Science paper about the six country study except that, since the livestock mostly died in Honduras and hence the income and NPV impact was negative, I exclude that country and only take the five countries with positive results. ${ }^{6}$ The average income gain for the "treated" households in year 3 of the program is $\$ 344$ dollars (this is the "intention to treat" effect). What did that program cost? The five country average NPV of costs per household of the 24 month program was $\$ 4,545$.

\footnotetext{
${ }^{6}$ Though this obviously ignores the very real risk that a project will fail due to some exogenous calamity or circumstance and hence biases the ex ante rate of return in a positive direction.
} 
Figure 3: A rigorous evaluation of the "graduation" approach to the ultra-poor shows income gains in year 3 of $\$ 344$ on costs of $\$ 4,545$

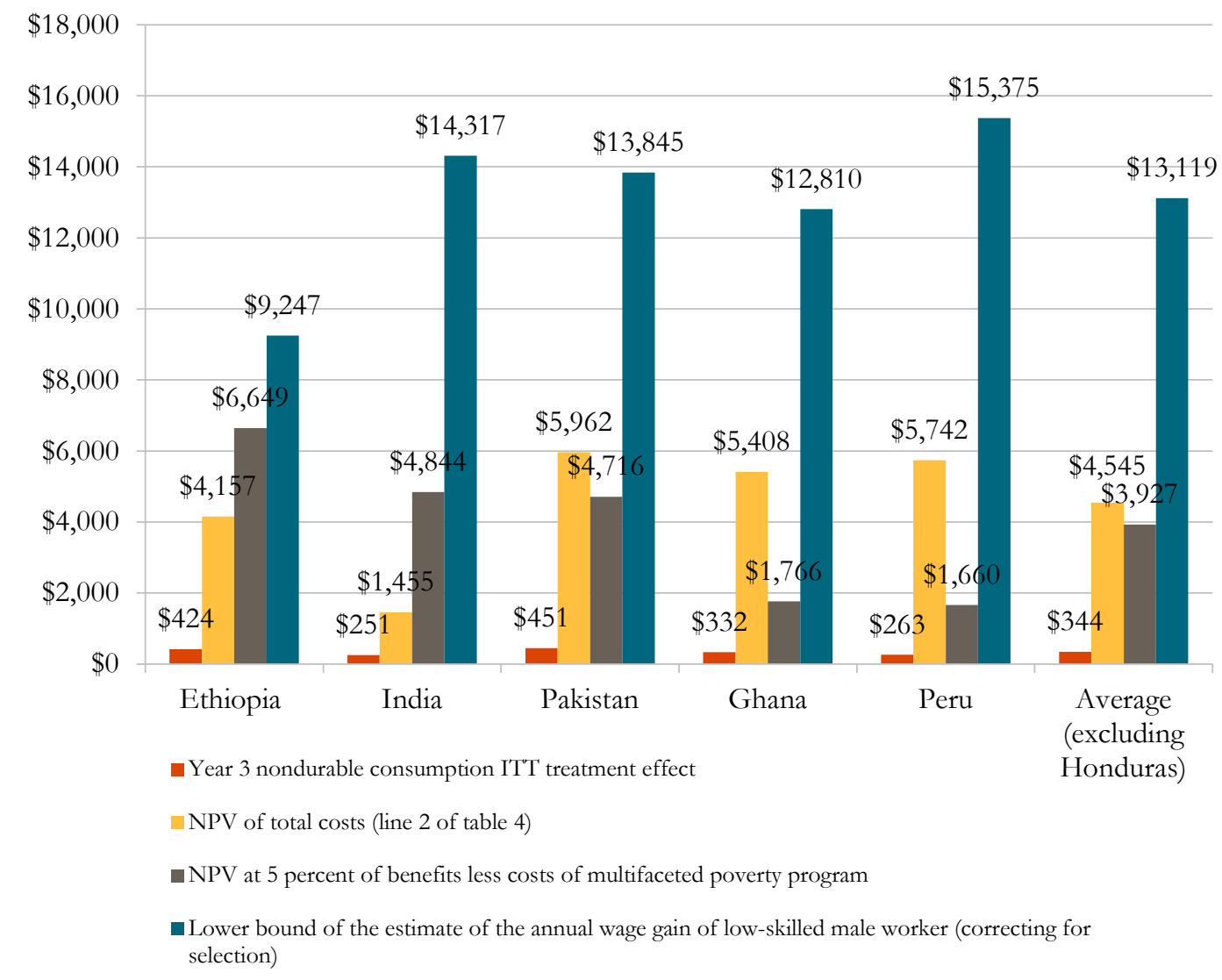

Source: Banerjee et al 2015 for the Graduation approach estimates, Clemens et al 2016 for gains from labor mobility.

Even though I knew (roughly) the Science paper numbers before I built the simple intuition it is still pretty striking how close the guess that it would take $\$ 5,000$ to produce $\$ 277$ in gains is to the empirical estimate that the Graduation approach costs $\$ 4,545$ to produce $\$ 344$ in gains. On the assumptions the authors make about the future gains (all that is really empirically estimated is the year 3 impact) they estimate an NPV at 5 percent of the lifetime gain of $\$ 3,927$. The IRR of this, paying $\$ 4,545$ to produce 50 years of a flow of incremental income $\$ 344$ is 7.4 percent. This is less than a 10 percent rate of return (implying the NPV of this project at 10 percent is negative).

Blattman and Niehaus (2014) have argued that in philanthropic giving to benefit the world's poor we should think of cash as the "index fund." That is, suppose I wanted to invest X dollars in the US stock market at its 1966-2015 real return of 5.4 percent to provide an annual payout to a household in a poor country of $\$ 344$ (with pure electronic transfer and hence no transaction costs). Then I could do this with $\$ 6,370$. So in the case of the "Graduation approach" as implemented in these countries in this particular Science study, the "best you can do" beats cash—but not by an astounding amount. Moreover, there are 
lots and lots of programs that spend money to deliver goods, assets, training, etc. to the poor that do much worse than cash (as many spend the money and have no sustained impact on incomes and many spend lots of money to produce small gains).

When many people think of philanthropy they often don't think of cash or incomes, they think of giving specific items or treatments that improving people's lives directly-like food, or scholarship for school, or a bed net in malarial areas or building a toilet. But roughly the same logic applies here as it would be very hard to give someone a specific good in a way that makes them better off in their own evaluation than just having the equivalent amount of cash. ${ }^{7}$ Dupas and Miguel (2016) review studies of the Take-It-Or-Leave-It (TIOLI) purchase rates - the fraction of people who will purchase something at various prices — of various health promoting items from vitamins to soap to latrine slabs to bed nets. They find that purchase rates - which are the revealed preference indicator of the consumer's valuationare very low even at a small fraction of the costs. For instance, a water filter in Ghana that cost $\$ 15$ elicited only a 10 percent purchase rate even at the highly subsidized price of less than $\$ 6$. A $\$ 15$ dollar latrine slab in Tanzania had only a 20 percent purchase rate at $\$ 6$.

Obviously spending $\$ 15$ dollars to give someone something they would not themselves buy for $\$ 6$ implies they would (much?) rather have the $\$ 15$ dollars. This gain makes the case that to create $\$ 15$ dollars of value for a poor person is generally going to cost at least $\$ 15$ dollars.

${ }^{7}$ Of course there are some goods that have positive externalities, as is argued for de-worming (Miguel and Kremer 2004) or sanitation, such that the total social gains are larger than the sum of the individualized willingness to pay. 
Figure 4: People typically value specific preventive health items at much less than their cost, for example in Kenya only 20 percent would buy a $\$ 7$ dollar bed net for $\$ 3$

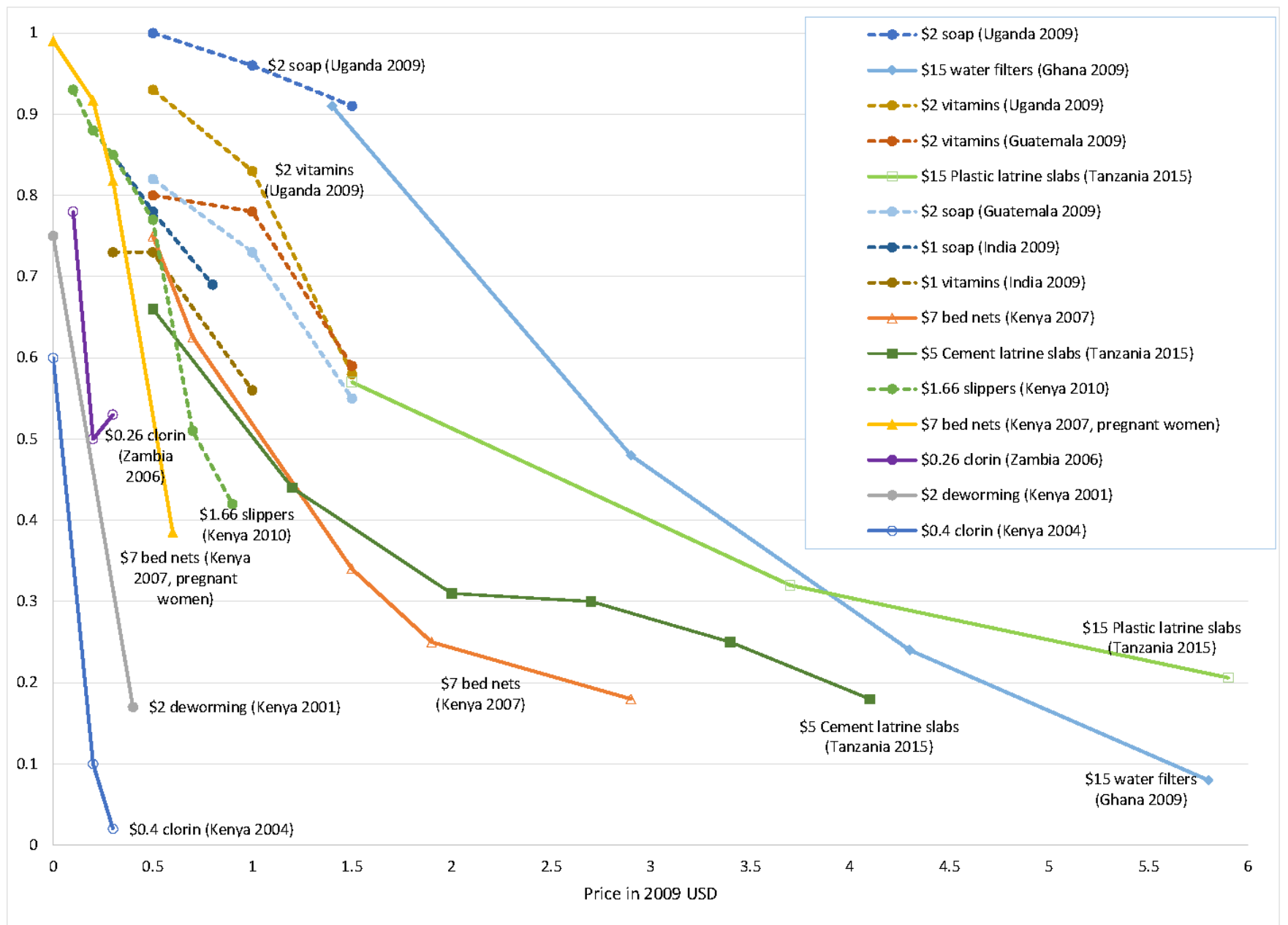

Figure 2 notes: The data sources are Cohen and Dupas 2010, and Dupas 2014 for bednets; Kremer and Miguel 2007 for deworming; Ashraf et al. 2010 and Kremer et al. 2011 for chlorine; Meredith et al. 2013 for soap, vitamins and slippers; Berry et al. 2015 for water filters; and Peletz et al. 2016 for latrine slabs.

Source: Figure 2 from Dupas and Miguel (2016).

The valuation question makes it difficult to assess most of the newly minted "rigorous" (RCT based) evidence about the impact of projects on human well-being. For instance, Vivalt (2015) has done the Herculean $\operatorname{task}^{8}$ of assembling the available RCT evidence to investigate whether or not findings are generalizable. She comes up with 20 different interventions (e.g. deworming, conditional cash transfers, microfinance, rural electrification, etc.) for which there are sufficient rigorous studies to compare the results. However, "total

${ }^{8}$ Mostly Herculean in the sense of the task of King Augeas' stables. 
income" (or any other variable that allows a straightforward valuation) is an outcome variable for only five of these types of interventions. ${ }^{9}$ For the others the outcomes on which the impact is assessed are variables like height for age (for micronutrient supplementation), or enrollment rate (for conditional cash transfers), or diarrhea incidence (for safe water storage). With these, even if we know a project had a positive and statistically significant impact on the outcome we have no way of knowing whether this was a high impact on wellbeing intervention or better than a cash transfer without a clear valuation of the outcome (e.g. what is a unit of height for age worth in terms of human well-being or welfare or willingness to pay?).

All of this is not an argument against philanthropy, which is easily justified on redistributive grounds. That is, if marginal utility is declining in levels of income, say utility is the natural $\log$ of consumption, then the marginal utility is 1 /consumption. This implies a dollar's worth of consumption in utility terms of a person at the global poverty line is worth 64 times as much as a dollar to person in the highest decile of consumption in the USA $(63.6=(1 /(1.9 * 365)) /(1 / 44,152)$ so transferring income from a rich person in the USA to a globally poor person produces, in and of itself, massively higher total global utility (even if not Pareto improving). The "cash as an index fund" approach is that rich people donating money that is spent in transaction costs to deliver something someone values less than a dollar isn't optimal. But even if a rich person got only 20 cents to a poor person for each dollar sacrificed this still has 13 times more marginal utility than the rich person's consumption at $\log$ utility. And for the real rich, who may have consumption ten times that of the average top decile in the USA, the case for philanthropy is overwhelming as the marginal utility of the poor would be over 600 times that of the extremely rich and hence even massive ineffectiveness would not offset this positive gain from giving.

So, I am not saying that transfers to those who are poor (either via philanthropic or government programs) somehow makes people worse off (or no better off). I am just making the pretty common sense argument that transfers will make them better off by about the cash value to them of whatever is transferred, which for people in the condition of having very low income/consumption imply a very large increase in utility or well-being terms. ${ }^{10}$ While there are sophisticated arguments for in-kind versus cash as mechanisms for transfers, there is little or no empirical evidence that we should expect in-kind programs to have enormously larger impacts on well-being (say, a factor of two) than just transferring cash. And there are inevitably administrative costs of any program and hence the cost to transfer a dollar to a person is inevitably going to be larger than a dollar. I think the case for

\footnotetext{
${ }_{9}^{9}$ And for these five the impact on income is very mixed, suggesting the Graduation program is the "best you can do." For instance of the 5 studies on microfinance that Vivalt reports 3 find a statistically insignificant impact on income and two find a positive impact. And finding the impact is positive is only a step towards finding it has a high return or would be better than cash.

${ }^{10}$ Since we are considering dynamics, targeted programs can either attempt to target people who are chronically poor or target people who are temporarily poor (Pritchett). All insurance transfers purchasing power from good states to bad states from times in which your house doesn't burn down or your car isn't crashed when you pay the insurance premium to times in which the bad state occurs.
} 
philanthropic transfers from rich country citizens into cost-effective transfers to people in poor countries is quite strong.

\section{II) The place premium and "A" (Total Factor Productivity)}

I want you to believe something pretty astounding. I am arguing that, as a way of helping the global poor either you can spend $\$ 4,545$ dollars and produce annual income gains of $\$ 344$ (and again this is not the average case but near the best case) or you can produce annual income gains of $\$ 17,115$ for free. I owe you a convincing explanation of how this can be so. The answer is "A." 11

When economists do growth economics they write an equation for a countries aggregate value added or income (y) as a function of the stuff it deploys to produce that output or "factors": machines, trucks, buildings (k), raw labor power (l) and skills and capabilities that augment labor power (hk) and this function is multiplied by " $\mathrm{A}$ " on the assumption that there is something that can enhance the productivity of all factors. This would hold for a given country (i) at a given time (t):

$$
y_{i, t}=A_{i, t} f\left(k_{i, t}, h k_{i, t}, l_{i, t}\right)
$$

Or, in words:

Country value added at a point in time $=$ (Productivity of factors in the place)*(Production function that depends on the magnitude of the factors deployed in the place)

Turns out, a huge amount of what development economics is about is "what is A?" and "how does a country get more A?" In the earliest versions of "growth economics" (e.g. the Solow-Swan models and variants) which was about the evolution of output in richer countries "A" was assumed to be mostly like a set of blueprints of possibilities and it was thought that "technical progress" caused A to go up over time. This was consistent with common sense-it is pretty obvious that over the course of the $20^{\text {th }}$ century there were lots of new technical possibilities-e.g. electricity, internal combustion engines, new seeds and fertilizers, telephones, computers, airplanes. Thus, it stood to reason that the same stock of capital (k), skills (hk), and labor (l) should be able to produce much more in the USA in 2000 than in 1900 (e.g. Gordon 2016). This has led to huge literature of estimates of the evolution of TFP or "multi-factor" productivity.

11 Which is so much more persuasive than if I were arguing it was "B." 
The $y=A * f(s t u f f)$ model was adopted not just a guide to rich country's past growth, but also as a guide to cross-national differences in income. ${ }^{12} \mathrm{On}$ the assumption that $\mathrm{A}$ was codifiable knowledge like blueprints it was assumed that A would converge rapidly and hence poor countries would have high returns to investments in the accumulation of factors, like capital (private and public) and human capital and hence the growth dynamics of poor countries would be driven by the ability to mobilize investible resources (domestic and foreign savings) to finance those investments. This was the "two gap" (savings gap and foreign exchange gap) model that grounded/founded the multilateral development organizations and their instruments. It has taken a very long time, and lots and lots of data to realize (with Bill Easterly) that "The central problem in understanding economic development and growth is not understanding the process by which an economy raises its savings rate and increases the rate of physical capital accumulation" (Easterly and Levine 2001) — which is of course the exact contradiction of Lewis (1954).

What we now realize is that most of the differences in levels of output per worker across countries are not accounted for by the usual measures of "capitals" or factors but rather that A accounts for most of the differences (Casselli 2005). In fact, rather than A converging rapidly as one might have expected from a spread of "technology" it is differences in the growth of A that is contributing to divergence as A was (before the crisis of 2008, more recent events may have shifted that) growing more slowly in poor countries than rich countries (e.g. Bosworth and Collins 2003, Grier and Grier 2007). Economists then attributed the differences in A not to "technology" but rather to other, deeper features, called "social infrastructure" (Hall and Jones 1999) or "institutions" (North, Wallis and Weingast 2013, Acemoglu, Johnson and Robinson 2001, Rodrik, Subramanian and Trebbi 2002). Another strand of work stemming from Ricardo Hausmann and collaborators has attributed productivity to the difficulty of the diffusion not of codifiable or embodied knowledge but of the capability and know-how or organizations and systems. Still another strand of research pointed out the problem was not so much that no firms achieved high A but that some economies appear to allow persist of low productivity firms and hence persistent differences in productivity across firms account for some of the "TFP."

The important point is that the productivity of " $\mathrm{A}$ " is a characteristic of a place and is not owned and controlled by a person (as labor power and skills intrinsically are and as a machine or building or property can be). This means that the productivity of a person might not be due to their own efforts or assets or choices but the productivity of the place in which they utilize those assets. And therefore if countries limit the mobility of labor through binding and coercive border based barriers this can generate massive differences in wages for people with exactly the same intrinsic productivity because it generates wedges in their market clearing price because of the difference in their labor's marginal productivity between the two places.

\footnotetext{
12 This was in spite of the warnings from John Hicks that models of comparative steady state growth paths which, of technical necessity, assumed that all sectoral shares were constant, was the field of economics of least relevance to development economics.
} 
This is the deep sense in which labor mobility is the "least you can do" because the gain in wages is due to higher place based marginal product of labor so the person makes higher wages because an employer (or buyer) will willingly pay them for their higher productivity. Economically this means the wage gains are better than free-these wages gains are efficiency enhancing and hence are Pareto Optimal and hence potential strictly Pareto Improving (meaning, with the right distribution of the gains, literally everyone could be better off). This is not saying that there would not be losers but that the gains from the gainers are sufficient to compensate all losers and still have gains. Of course this brackets lots of questions about the labor market and fiscal consequences of labor mobility for the host country but those are literally and figuratively second order of small and could, from a technical standpoint, easily be addressed..$^{13}$

All of the calculations presented are "at the margin" in the sense that we assume that the arrival of a worker does not lower A in the host country. For small increases this is perfectly reasonable as no one suspects having one more Nepali in Switzerland is going to reduce its A (factor productivity). But some have claimed that immigrants might bring "low A" with them and that even if this isn't true at the margin (after all, if A is embedded in rules, laws, policies, norms, institutions, etc. it is hard to see how a few more people at the margin could change that) that there might be non-linear impacts such that large increases in the numbers of people moving across borders in a short period of time might shift these and reduce $A$ in the host countries (e.g. this has been argued by Paul Collier and George Borjas). Three responses. First, nothing I have said is about "open borders" it is about "more mobility" and the calculations are all about manageable increases-like 3 percent of the labor force increases - that would be hard to suggest would undermine A starting from given levels.

Two, this is a conjecture and there is, as yet, no evidence that any country is at or near such a threshold. OECD countries already differ by an order of magnitude in the ratio of developing country foreign born to natives in their population but there is no evidence $\mathrm{A}$ or the growth of $\mathrm{A}$ is lower in the countries with more foreign born (Clemens and Pritchett 2016). Three, in Clemens and Pritchett (2016) we build and calibrate a model that allows for non-linear effects of the stock of labor from foreign countries on A (like that proposed but not actually fleshed out by Collier). This model suggests that the empirical evidence is consistent with countries being able to sustain much higher flows of migrants than current flows without crossing any thresholds that would reduce A.

The upshot is that places like Haiti are just an extremely unproductive place to use factors of all types - including labor. Investing in increasing someone's income in Haiti by helping them acquire more assets (including more schooling or training) can be expected to produce

\footnotetext{
${ }^{13}$ I am not being cavalier about the potential political or administrative complexities in addressing these issues, but technically they are straightforward. For instance, it is argued that low-skill migration harms the host country because the fiscal contribution of the migrants is less than their fiscal burden. But this is a feature entirely under the control of the design of the labor movement. That is, if the worry is that children of migrants are using local schools then they (or their employer) could be charged a fee for each child enrolled. Or migrants might have to "buy into" eligibility for social programs. This is about distributing the potential gains between mover and host country and leads to difficult choices from a social, political, or ethical viewpoint but technically (and pragmatically in most countries) they are easy. In many countries today nothing is politically "easy."
} 
only modest gains because those resources are used in Haiti, which is a low A place. As Clemens and Pritchett (2008) show 36 percent of all Haitians who are not poor at the old (non-inflation adjusted) "two dollar a day" standard live in the USA and of those above a "middle class" threshold of "10 dollars a day" fully 82 percent of all Haitians who are globally "middle class" (or not "global upper bound poor") are living in the USA. Moving from Haiti to the USA moves a person with the same intrinsic productivity from a low A place to a high A place and hence increases output.

\section{III) "Foreign aid" and its impact versus immigration}

With the distinction between "accumulation of stuff" and "factor productivity" models of economic growth we can return to the question of the impact of foreign aid. I think when people talk about "foreign aid" there are three fundamentally different modalities they might have in mind about what "foreign aid" is and does:

- FA:MT (foreign aid as macro transfers): is principally the transfer of investible resources at the macroeconomic scale to alleviate the "two gap" constraints (domestic savings and foreign exchange) on the accumulation of productive resources to accelerate economic growth. This can be done with the financing or projects or through budget support (either quick disbursing or time slice financing) or other means. This was traditionally government to government or multi-national government-like (e.g. World Bank, IADB) to government transfers. This supported investments in a variety of sectors, including education and health.

- FA:TP (foreign aid as targeted programs): is primarily about "poverty reduction" or "meeting basic needs" through specific programs targeted to individuals to increase the assets or productivity of "the poor" (or transfers) or to provide specific goods (e.g. education, health) to "the poor." This is a more recent emphasis and is primarily that of philanthropists (but has burrowed into development organizations).

- FA: IR (foreign aid as vector of ideas and research): is primarily about creating the conditions in which knowledge and know-how to increase productivity through improved policies and capability to implement policies to both accelerate economic growth and for governments to effectively deliver needed services.

Let's briefly review each of these.

FA:MT. The literature on the first question of whether the flow of FA:MT promoted or not economic growth is long, deep, and divided. It is obvious that many countries that got very little "foreign aid" as a percent of GDP did grew very well (e.g. Korea (since 1962), China (since 1978), India (since early 1990s), Vietnam) and countries that got relatively large amounts did quite badly in some periods in which they were receiving lots of assistance (e.g. Tanzania (Edwards (2014)). I think it is safe to say that foreign aid did not have the kind of huge impact that the early two gap models suggested it should have. Beyond that, there are three schools, all of which have some modest amount of empirical support and each of 
which is defended by prominent economics and I am not going to write the long review necessary to properly adjudicate the conflicting claims: (a) that FA:MT had zero or close to zero impact (and the returns did not vary much by policy or institutional conditions) (e.g. Boone 1996, Rajan and Subramanian 2008, Easterly, Levine and Roodman 2004), (b) that the returns to aid are (near) zero on average but this is because of the interaction between the effectiveness of FA:MT in impacting growth and "good policy" (e.g. Burnside and Dollar 2000 (though the Easterly, Levine, and Roodman 2004 comment shows the fragility of these empirical results), Collier and Hoefler 2004), and (c) that FA:MT has about exactly the impact on growth a standard neoclassical model with standard returns to aggregate investments suggests it would have (but not a two gap model), perhaps with some interactive effects on non-policy variables (e.g. Dalgaard, Hansen and Tarp 2004, Arndt, Jones and Tarp 2010, Clemens, Radelet, Bhavani and Bazzi 2012).

The upshot of all of this is that no one, especially aid sceptics but even evidence using aid enthusiasts claim that at the margin transfers of financial resources through foreign aid can have anything like the rate of return to relaxing border based barriers. For instance, total development assistance as measured by the OECD DAC in 2015 was 131.6 billion dollars. If the gain to each low skill worker who moves is $\$ 17,115$ then only 8 million workers would need to move to produce 136.92 billion in additional gains. While this might seem like a big number of people to move, it is only 1.5 percent of the OECD labor force. These crude, back of the envelope, type calculations are consistent with more sophisticated world general equilibrium models showing that a 3 percent increase in the OECD labor force through relaxed restrictions on labor mobility would produce $\$ 150$ billion (in 1997 prices) in global welfare gains (adding up gains to movers, gains/losses in host countries and gains/losses in sending countries). World Bank (2006) suggests a 3 percent increase in OECD labor force over a 10 year period would lead to $\$ 674$ billion in global welfare gains -5 times total development assistance.

These macro comparisons play out at a bilateral scale as well. New Zealand introduced a program of seasonal agricultural workers from Pacific Islands and this program was the subject of a randomized evaluation of the benefits to moving workers (made possible by the random selection of those allowed to move from potential applicants to control for selectivity). The evaluation found that for the 1971 workers who moved the net gains were 5.3 million NZ dollars (McKenzie et al 2010). The total bilateral assistance from New Zealand to Tonga was 12 million NZ dollars. So, even assuming NZ aid produced dollar for dollar the same well-being gains as money in a Tongan's pocket, just allowing less than 2,000 people to move seasonally to New Zealand to work for farmers who were willing to pay the full cost produced nearly half the benefits of New Zealand's foreign assistance.

FA: TP. The idea of "foreign aid" as "targeted programs" (rather than addressing "national development") is what was addressed above-even though this has not been the traditional understanding of development or development economics this has gotten more attention, again particularly with the rise of philanthropic engagement. But, as we saw above, and will see below, this is more the mitigation of the lack of development than an actual development strategy. The one objection to the idea of labor mobility as an alternative to these directly targeted in situ programs is the concentration of the benefits. That is, nearly all 
of the benefits of moving accrue to the mover and those linked to the mover through remittances and the $\$ 17,115$ of benefits go to one person whereas a Graduation-like program may only generate $\$ 344$ in benefits per household per year but the program can potentially cover many households (but, keeping in mind that is costs $\$ 4,500$ up front per household to generate this amount). This concentration is true, but schemes of temporary mobility that were rotational (rather than the same number of "permanent" migrants) could mitigate this concentration issue.

Nothing I am saying suggests that altruistic people should do less of financing of effective targeted programs like Graduation. Rather, I am pointing out that as an altruistic strategy for the global poor this is an extremely unbalanced portfolio of activities and it is odd the extent to which people are willing to do actions with small returns in situ but not facilitate movement with orders of magnitude larger gains and smaller or zero (net) costs.

FA: IR. All that said, I don't want to give the wrong impression about the course of development. If one examines the "development era" since 1950, in which there has been a self-conscious global movement promoting national development, the period from 1950 to 2010 has been the best 60 years for progress in human development on (nearly) every measure in the history of mankind. On many measures - schooling, health, GDP per capital, headcount low bar ("dollar a day"), etc. there has been more progress in the last 60 years than in all the previous recorded human history combined.

For instance, the average schooling of an adult in the developing world in 1950 was 2.1 years and in 2010 this was 7.1 years. This means from the beginning of humans to 1950 progress was 2.1 years and from 1950 to 2010 the gain was 5 years-more than twice as much progress in 60 years than the previous 6,000 years combined. ${ }^{14}$

For another example, the historical Maddison data on output per capita suggest the lowest demographically sustainable income is around $\$ 400$ (in 1990 Geary-Khamis PPP dollars). In those units 1950 world income was $\$ 2,104$, a gain over the long-run historical minimum of $\$ 1,704$. In 2010 global income was $\$ 7,814$. While this is global (not just "developing" countries) there was massive more progress in labor productivity in 60 years from 1950 to 2010 than in all previous human recorded history combined.

So the issue with "foreign aid" is that it is difficult to parse out credit for success, not explaining failure. That is, the question is not "why has development failed to improve outcomes because outcomes are not better?" Although of course some countries have had very little progress in GDP per capita or material poverty, most countries have, and, even in those countries with little or no economic progress there has generally been massive expansions in schooling and improvements in health. So, by and large, there has been massive progress in developing countries, in many countries the progress has been superrapid in many dimensions (e.g. Korea post-1962, China post-1978, Vietnam post-1989,

${ }^{14} 6,000$ years is chosen to be evenly divisible by 60 , not because of Biblical literalism. 
Indonesia post-1967). The question is "has foreign aid played any role in the massive successes of the development era, and if so, what was that role?"

To use a sports analogy after a team has won a championship many of the players who are free agents will suggest they deserve a raise for having played a key role in the championship. The question is not whether the team won, it did, the question is the attribution of the win to the particular player - which in a truly team sport may be impossible (Pritchett 2017). Certainly the gains in human well-being over the last 60 years, like all successes, have many mothers and fathers - health breakthroughs, technological shifts, spread of political and economic freedom-but the question is parsing credit for success not blame for failure.

This is important because the gains to countries from episodes of growth acceleration and the losses from growth decelerations/collapses are similarly huge. Therefore any action or expenditure or investment in ideas that has any role in changing the probabilities of growth accelerations or growth decelerations will have astronomical (ex post) returns and potentially high ex ante returns.

Let me give an example from India. ${ }^{15}$ A combination of political and policy circumstances had put India in a very precarious situation and on the brink of exactly the kind of macroeconomic crisis that occasioned the "lost decade" of growth in Latin America in the 1980s (which was really more like a lost two decades). The Indian government ultimately took a series of steps that most people regarded both as a good handling of the short run crisis and a decisive break with a past economic strategy and a new policy stance.

A recent study I was part of used common statistical procedures across all countries to estimate the dating of growth episodes and how much total Net Present Value (NPV) of GDP each episode created (or destroyed) relative to a "business as usual" counter-factual of growth during the episode period (Pritchett, Sen, Kar and Raihan 2016).

This procedure says that, rather than a growth slowdown in India, there was a growth acceleration in 1993 that created 1.1 trillion in additional GDP. Then, there was another growth acceleration in 2002 that created another 2.5 trillion in GDP (over and above the previous acceleration and both of these are over and above the "business as usual" or "expected" growth). Together, relative to the "business as usual" trajectory there has been 3.6 trillion dollars in gain (this cumulative additional GDP is larger than the annual total of the UK or France of about 2.8 trillion). ${ }^{16}$

\footnotetext{
15 This section is based on Pritchett 2017.

${ }_{16}$ Two comments. One, these growth accelerations did, eventually, produce substantial reductions in poverty. Two, as suggested by the pathways out of poverty in Figure 2 the impact evaluation of the Graduation approach project in South India found, unlike the Science article above, no lasting impact on income for the "treatment" group (Bauchet, Morduch, and Ravi 2015). This was in part because wages for unskilled labor were rising rapidly and hence many people dropped out of the Graduation program of asset transfers to get a job that produced larger income gains.
} 
What caused this additional gain? Of course, no one is really sure exactly what it was and how to parse out the factors and simplistic (e.g. "trade reform caused it") explanations are almost certainly, well, simplistic. But something did happen and it almost certainly had to do with deft handling of the macro-economy plus a well-executed shift in strategy towards greater reliance on markets and more openness to the global economy (which is again not saying anything simplistic like that "laissez faire" was the answer or that India turned into a "neo-liberal" state).

Who caused this additional gain? In order to achieve a national policy shift there were of course hundreds, if not thousands of people who participated in producing evidence, disputing explanations of India's past growth, examining alternatives for the future. But let me single out one group. The ICRIER (India Council on Research on International Economic Relations) was a think tank founded in 1981 that, according to its $20^{\text {th }}$ anniversary document:

"The Indian Council for Research on International Economic Relations (ICRIER) was established in August 1981 as an autonomous, policy-oriented, not-for-profit, research institution. This initiative was intended to foster improved understanding of policy choices for India in an era of growing international economic integration and interdependence.

"The concept of ICRIER emerged from the Steering Committee for Research on International Economic Relations (SCRIER) to enable policy makers, civil society and academia in India to examine intended and unintended consequences of policy choices concerning globalisation, taking a more open and inclusive view of the world. The first advisory panel, chaired by K B Lall, included I G Patel, Jagdish Bhagwati, Malcolm Adiseshiah, Montek Singh Ahluwalia, C Rangarajan, Fredie Mehta, and Manu Shroff."

And, in the section of the $20^{\text {th }}$ anniversary document discussing the funding of ICRIER:

"The Ford Foundation deserves special mention for providing initial funding in 1982 and now, 20 years later, supporting a significant expansion of ICRIER's endowment base."

There is a narrative in which Ford Foundation, a global philanthropy provides some millions (or tens of millions) of dollars of funding that play some role in creating a think tank that itself then plays some role in providing the conditions in which good policy choices are made that then results in the creation of 3.6 trillion in additional output of Indians. Suppose the Ford Foundation gave 36 million dollars (I have no idea what it really was but I strongly suspect this was the right order of magnitude and I just make it divisible) to support ICRIER.

Optimistically, suppose this gift increased by 50 percent the chance ICRIER was created and became an effective think tank (perhaps other funding could have come along, perhaps not) and suppose the existence and actions of this think tank increased by 10 percent the odds 
India adopted growth accelerating policies (my read of the situation is that it was higher). Then the expected value of Ford Foundation's 36 million of support was 180 billion dollars (bracketing discounting) a 5000-fold return per dollar of investment.

Pessimistically, suppose the Ford Foundation funding only increased the likelihood of an effective think tank by 10 percent (someone else almost certainly would have funded it) and the impact of ICRIER on the likelihood of a growth accelerating policy outcome was only 1 percent, the investment still returns 100-fold-3.6 billion in additional output on 36 million.

This same growth procedure of identifying magnitudes of gains and losses from growth accelerations and decelerations was applied to all countries and the results show many episodes in which the total gains and gains per person from the cumulative effect of a sustained episode of rapid growth were massive. In China they growth accelerations in 1977 followed by another in 1991 added 14.3 trillion dollars in NPV(at 5 percent discount rate). The growth acceleration in Indonesia in 1967 that lasted until 1996 added over a trillion dollars— $\$ 9,712$ in NPV per person. The growth acceleration in Vietnam in 1989 added $\$ 6,914$ per person. While this is unfair to our migration numbers (as this is NPV versus annual flow) at least the numbers are comparable. And the gains are average per person in the population and so the totals are on the order of the achievable totals from labor mobility. To achieve the total gains in annual flow of the cumulative NPV of Indonesia's growth acceleration in 1967 would require 65 million migrants at $\$ 17,115$ per migrant (again that is comparing a flow (mobility) to stock (total gain) so overstates the number to match a flow to flow). 
Table 3: Estimated NPV total and per person gains from the largest episodes of growth accelerations are on the same order of magnitude with gains from labor mobility

\begin{tabular}{|lccc|}
\hline Country & $\begin{array}{l}\text { Year of } \\
\text { growth } \\
\text { acceleration } \\
\text { episode }\end{array}$ & $\begin{array}{l}\text { NPV (@ 5 percent) of output gain } \\
\text { from growth acceleration (in billions of } \\
\text { dollars) }\end{array}$ & $\begin{array}{l}\text { NPV gain from growth acceleration } \\
\text { per person }\end{array}$ \\
\hline China & 1991 & $\$ 11,786.52$ & $\$ 10,129$ \\
\hline China & 1977 & $\$ 2,655.71$ & $\$ 2,807$ \\
\hline India & 2002 & $\$ 2,523.38$ & $\$ 2,426$ \\
\hline Indonesia & 1967 & $\$ 1,119.03$ & $\$ 9,712$ \\
\hline India & 1993 & $\$ 1,097.62$ & $\$ 1,238$ \\
\hline Poland & 1991 & $\$ 1,048.22$ & $\$ 27,402$ \\
\hline Taiwan & 1962 & $\$ 877.15$ & $\$ 73,593$ \\
\hline Vietnam & 1989 & $\$ 455.44$ & $\$ 6,914$ \\
\hline Korea & 1962 & $\$ 421.17$ & $\$ 15,941$ \\
\hline Thailand & 1958 & $\$ 309.17$ & $\$ 11,962$ \\
\hline Malaysia & 1987 & $\$ 197.96$ & $\$ 11,940$ \\
\hline Chile & 1986 & $\$ 184.20$ & $\$ 15,024$ \\
\hline Dom Rep & 1991 & $\$ 104.46$ & $\$ 14,458$ \\
\hline Singapore & 1968 & $\$ 59.04$ & $\$ 29,344$ \\
\hline
\end{tabular}

Source: Selected episodes. Author's estimates from estimates in Pritchett, Sen, Kar, and Raihan 2016

But, countries also have growth decelerations that causes losses in output (relative to the nongrowth-deceleration counter-factual). Table 4 shows these losses in NPV and NPV per person. Brazil had a growth slowdown in 1980 that lasted (according to the Pritchett et al 2016 procedure) until 2002 in which there was zero percent growth from 1980 to 2002. The estimated loss from this growth slowdown was 7 trillion dollars or $\$ 61,353$ dollars in lost NPV per person in Brazil. Had policy action been able to avoid that slowdown, or mitigate how far growth fell, or cut short the duration of the stagnant episode potentially trillions of dollars of output could have been saved. Côte d'Ivoire had a growth slowdown in 1978 that caused a long decline lasting (at least) until 2010. This produced a cumulative NPV per person loss of $\$ 15,000$. Again, had anything been able to pull Côte d'Ivoire out of this downward spiral in output it would have had enormous benefit to very poor people. 
Table 4: Losses in NPV (total and per person) from growth decelerations relative to the counter-factual are also massive

\begin{tabular}{|lccc|}
\hline Country & $\begin{array}{l}\text { Year of growth } \\
\text { deceleration }\end{array}$ & $\begin{array}{l}\text { NPV(@ } \mathbf{5} \text { percent) of output loss } \\
\text { from growth deceleration relative } \\
\text { to counter-factual growth (in } \\
\text { billions of dollars) }\end{array}$ & NPV loss per person \\
\hline Brazil & 1980 & $-7,547.67$ & $-\$ 61,353$ \\
\hline Iran & 1976 & $-5,055.57$ & $-\$ 146,643$ \\
\hline Indonesia & 1996 & -922.53 & $-\$ 4,587$ \\
\hline Mexico & 1981 & -749.44 & $-\$ 10,711$ \\
\hline Nigeria & 1976 & -449.57 & $-\$ 6,771$ \\
\hline Venezuela & 1985 & -194.24 & $-\$ 11,427$ \\
\hline Venezuela & 1977 & -174.99 & $-\$ 12,958$ \\
\hline Côte d'Ivoire & 1978 & -121.05 & $-\$ 15,218$ \\
\hline Honduras & 1979 & -94.72 & $-\$ 28,886$ \\
\hline
\end{tabular}

Source: Selected episodes. Author's estimates from estimates in Pritchett, Sen, Kar, and Raihan 2016

The upshot is that given the dynamics of economic growth in developing countries and its potential dependence on choices made by political and policy actors the potential exists for massive gains in investment in ideas and research that is both (a) correct in how to encourage positive growth episodes and avoid bad episodes and (b) persuasive to politicians and policy makers.

The membership of the American Economics Association is about 20,000 and suppose the global total number of economists is twice that and the inclusive cost to someone of an economist per year is $\$ 150,000$ on average. Then the cost of all economists in the world is about 6 billion dollars. Suppose this was constant for 50 years and hence cost 300 billion to sustain the economics profession from 1960 to 2010. Suppose the only impact of all economists in all these 50 years was to be even a modest part of the many factors that persuaded the Chinese leadership to switch economic strategy and produce 14 trillion dollars in cumulative additional output.

How much was the optimal investment in macro-economic research prior to 1980 if more of it could have even cut in half the 7 trillion dollar loss in Brazil by having a less deep, less prolonged growth slowdown? Or the near trillion dollar loss from the Indonesian crisis in 1996 ? Or the $\$ 10,000$ perperson loss from the Mexican slowdown dated to 1981 ? On some level it is impossible to know as it is impossible to know whether more research ex ante would have produced answers that were correct and persuasive. But the total budget of the IMF is on the order of 1.2 billion dollars. If the IMF existed at that budget for 50 years at a cost of 60 billion cumulatively and all that it ever did was have a 10 percent chance of 
averting a single crisis that produced 600 billion lost growth, the entire investment in the organization would be justified.

About the only policy-like action that has anywhere near the welfare consequences of labor mobility are sustained episodes of rapid economic growth (and the losses from deceleration). Investments in creating accelerations and avoiding losses—even with small ex ante probabilities of success-have extraordinary returns. If that is what "foreign aid" doescreate and disseminate ideas that are adopted and have system-wide impact on big factors that affect well-being, then it could be well worth it. This also can apply to "foreign aid" that creates other policy actions with positive consequences-like encouraging more effective education or actions that effectively promote health—at the country wide level.

Allow me to combine with this the discussion above. Suppose the impact of the Graduation program in Ethiopia was what it was on average for the five countries and generated $\$ 1,720$ in NPV for each $\$ 1000$ invested (this is just dividing the household totals by 4 ). Then, if one were to invest a billion dollars into the Graduation program one could create 1.72 billion dollars in NPV. There are 104 million people in Ethiopia. So a billion dollars invested in an excellent anti-poverty program would increase per capita income in Ethiopia by $\$ 17$. Figure 5 compares that magnitude to the gains and losses from growth acceleration/deceleration episodes. The obvious point is that the gains from a billion dollars invested in an antipoverty program are a factor of 100 (e.g. India 2002 gain of $\$ 2,426$ per person) to a factor of 1000 (e.g. Korea's gain of \$15,941 per person from acceleration in 1962 or Côte d'Iviore's loss of $\$ 15,218$ per person in NPV from the deceleration in 1978) smaller than the gains and losses from growth episodes. The gains in Ethiopia from accelerations in 1992 followed by another acceleration in 2002 (valued only until 2010 because that is when the study data end) are $\$ 255$ per person.

The point is not that we, or anyone, can know for certain, or even with high reliability, that this or not action or research or advocacy or training that is supported by foreign aid will lead to a growth acceleration or help avoid a deceleration. But the potential gains and losses, measured from actual growth experiences, are just so enormous it is easy to justify pursuing those "public good" actions of creating research and discussion of ideas about development (particularly since they come at strikingly modest cost). For instance, the World Bank's internal expenditures (BB budget) on all of Development Economics (of which research is just a portion) in FY2016 was about 50 million dollars. The gains in NPV of GDP from just the Indian 2002 growth acceleration of 2.5 trillion are 50,000 times larger. The losses in NPV from Brazil's 1980 growth deceleration are 150,000 times larger. So even if by doing decades of research on what accelerates growth (or avoids losses) and even if that only as a small chance of success in changing policies this still could have just enormous returns-because the policy or other changes that create growth induces country-wide gains in A (which are, economically, free) and induces voluntary investments that have no direct fiscal cost (or conversely causes those to disappear). 
Figure 5: The per capita gains in NPV of GDP from a single large growth acceleration or the losses from a single large growth deceleration are 100 to 1000 times larger than the per person gains of a billion dollars devoted to an effective antipoverty program in Ethiopia

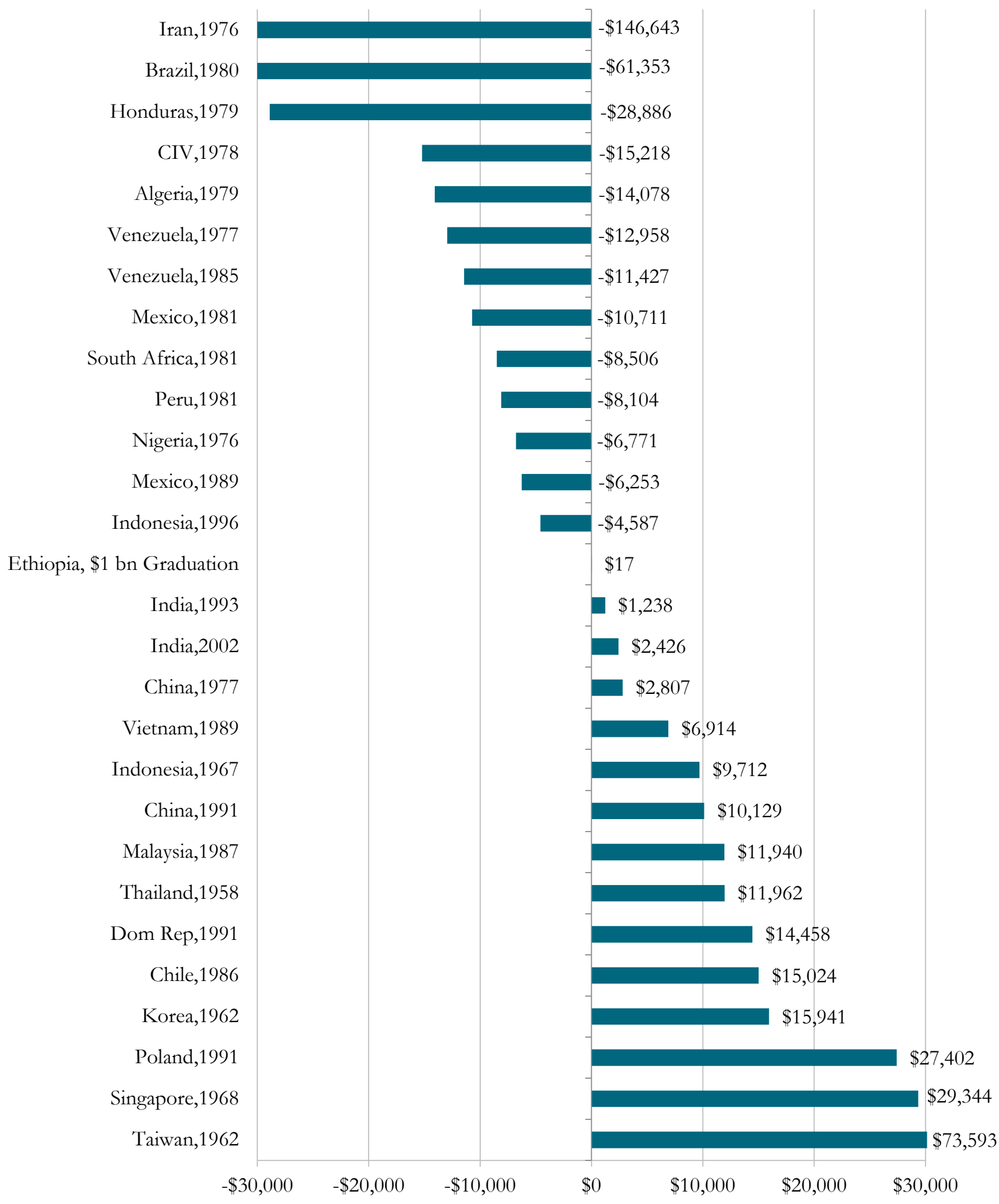

Source: Author's calculations from results in Pritchett et al 2016. 


\section{Conclusion}

A large part of the explanation of differences in labor productivity across countries is differences in "A" - total factor productivity. Transmitting A from country to country has proven difficult. This implies that labor with the exact same intrinsic productivity will have much higher productivity (and hence justify a higher wage) in a high A than in a low A country. But, by and large, rich countries have passed extraordinarily strict regulations on the movement of unskilled labor. A relaxation of these restrictions could produce the largest single gains in global poverty of any available policy, program or project action. And since these gains to movers are (mostly) due to higher A which (at the margin) is a "public good" (it is non-rival and non-excludable) in the host country these gains are essentially free to the host country (or could be free to the host country under some technical design conditions).

One thought for addressing the injustice of condition of birth based discrimination that keeps people in low productivity places is to imagine that rich country citizens will carry out philanthropic activities that raise the incomes of the global poor in situ. But the fact they are in low productivity places means it will be costly to raise their income in those places. Extrapolating from the fact that a "best in class" anti-poverty program produced, on average across 5 countries, $\$ 344$ in annual gains in income for the poor with $\$ 4,545$ in costs, to produce the annual gains of allowing a low skill worker to work in the USA of $\$ 17,115$ would require an investment of $\$ 226,000$ per person — versus producing those same gains essentially for free by relaxing barriers to mobility. The "best you can do" in situ is much less effective than the "least you can do" of letting people work and get paid a wage that reflects the value of their work.

That said, sustained rapid economic growth in developing countries - that is sustained by improvements in A—can also produce cumulatively enormous gains. And avoiding growth collapses/stagnation can prevent enormous losses. So, even though traditional measures of the country to country transfers of resources via "foreign aid" do not, in and of themselves, appear to be responsible for producing most of the observed differences in economic growth, investments that could bring that about more sustained growth (both more sustained accelerations and fewer sharp and extended decelerations) could also have astronomical returns. And, to be clear, no reason why more labor mobility and sustained economic growth cannot go hand in hand in improving well-being. 


\section{References}

Acemoglu, Daron; Simon Johnson and James Robinson. 2001. "The Colonial Origins of Comparative Development: An Empirical Investigation." American Economic Review, 91(5), 1369-401.

Arndt, Channing; Sam Jones and Finn Tarp. 2015. "Assessing Foreign Aid's Long-Run Contribution to Growth and Development." World Development, 69(Supplement C), 6-18.

Banerjee, Abhijit; Esther Duflo; Nathanael Goldberg; Dean Karlan; Robert Osei; William Parienté; Jeremy Shapiro; Bram Thuysbaert and Christopher Udry. 2015. "A Multifaceted Program Causes Lasting Progress for the Very Poor: Evidence from Six Countries." Science, 348(1260799).

Bauchet, Jonathan; Jonathan Morduch and Shamika Ravi. 2015. "Failure Vs. Displacement: Why an Innovative Anti-Poverty Program Showed No Net Impact in South India." Journal of Development Economics, 116, 1-16.

Boone, Peter. 1996. "Politics and the Effectiveness of Foreign Aid." European Economic Review, 40(2), 289-329.

Bosworth, Barry and Susan Collins. 2003. "The Empirics of Growth: An Update." Brookings Papers on Econmic Activity, 2, 113-206.

BRYAN, GHARAD; SHYAMAL CHOWDHURY and AHMED MUSHFIQ MOBARAK. 2014. "Underinvestment in a Profitable Technology: The Case of Seasonal Migration in Bangladesh." Econometrica, 82(5), 1671-748.

Burnside, Craig and David Dollar. 2000. "Aid, Policies, and Growth." The American Economic Review, 90(4), 847-68.

Caselli, Francesco. 2005. "Chapter 9 Accounting for Cross-Country Income Differences," P. Aghion and S. N. Durlauf, Handbook of Economic Growth. Elsevier, 679-741.

Clemens, Michael A.; Steven Radelet; Rikhil R. Bhavnani and Samuel Bazzi. 2012. "Counting Chickens When They Hatch: Timing and the Effects of Aid on Growth." The Economic Journal, 122(561), 590-617.

Clemens, Michael; Claudio Montenegro and Lant Prithchett. 2016. "Bounding the Price Equivalent of Migration Barriers." Center for Global Development Working Paper No. 428.

Clemens, Michael and Lant Pritchet. 2008. "Income Per Natural: Measuring Development for People Rather Than Places." Population and Development Review, 34, 395434.

Clemens, Michael and Lant Prithchett. 2016. "The New Economic Case for Migration Restrictions: An Assessment." Center for International Development Working Paper No. 423.

Clemens, Michael;; Claudio; Montenegro and Lant Pritchett. 2008. "The Place Premium: Wage Differences for Identical Workers." CGD Working Paper Series \#148.

Dalgaard, Carl-Johan; Henrik Hansen and Finn Tarp. 2004. "On the Empirics of Foreign Aid and Growth*." The Economic Journal, 114(496), F191-F216.

Easterly, William and Ross Levine. 2001. "It's Not Factor Accummulation: Stylized Facts and Growth Models."

Easterly, William; Ross Levine and David Roodman. 2004. "Aid, Policies, and Growth: Comment." The American Economic Review, 94(3), 774-80. 
Edwards, Sebastian. 2014. Toxic Aid: Economic Collapse and Recovery in Tanzania. Oxford, UK: Oxford University Press.

Gordon, Robert J. 2016. The Rise and Fall of American Growth: The Us Standard of Living since the Civil War. Princeton University Press.

Grier, Kevin and Robin Grier. 2007. "Only Income Diverges: A Neoclassical Anomaly." Journal of Development Economics, 84(1), 25-45.

Hall, Robert and Charles I Jones. 1999. "Why Do Some Countries Produce So Much More Output Per Capita Than Others?" Quarterly Journal of Economics, 114(1), 83-116.

Lanjouw, Peter and Martin Ravallion. 1999. "Benefit Incidence, Public Spending Reforms, and the Timing of Program Capture." The World Bank Economic Review, 13(2), 257-77.

Lewis, W. Arthur. 1955. The Theory of Economic Growth. R.D. Irwin.

Mani, Anandi; Sendhil Mullainathan; Eldar Shafir and Jiaying Zhao. 2013. "Poverty Impedes Cognitive Function." Science, 341(6149), 976-80.

McKenzie, David; Steven Stillman and John Gibson. 2010. "How Important Is Selection? Experimental Vs. Non-Experimental Measures of the Income Gains from Migration." Journal of the European Economic Association, 8(4), 913-45.

Montenegro, Claudio and Harry Patrinos. 2013. "Returns to Schooling around the World." Background paper for the World Bank World Development Report 2013.

Narayan, Deepa; Lant Pritchett and Soumya Kapoor. 2009. Moving out of Poverty: Volume 2. Success from the Bottom Up. Moving out of Poverty Volume 2. Washington DC: World Bank and Palgrave Macmillan.

North, Douglas; John Wallis and Barry Weingast. 2009. Social Order: A Conceptual Framework for Interpreting Recorded Human History. Cambridge University Press.

Pritchett, Lant; Kunal Sen; Sabyasachi Kar and Selim Raihan. 2016. "Trillions Gained and Lost: Estimating the Magnitude of Growth Episodes." Economic Modeling, 33(June), 279-91.

Pritchett, Lant and Rebekah Smith. 2016. "Is There a Goldilocks Solution? "Just Right" Promotion of Labor Mobility."CGD Policy Paper 94. Washington, DC: Center for Global Development.

Pritchett, Lant; Asep Suryahadi and Sudarno Sumarto. 2000. " Quantifying Vulnerability to Poverty : A Proposed Measure, Applied to Indonesia." World Bank Policy Research Working Paper;No. 2437.

Rajan, Raghuram and Arvind Subramanian. 2008. "Aid and Growth: What Does the Cross-Country Evidence Really Show?" The Review of Economics and Statistics, 90(4), 64365.

Rodrik, Dani; Arvind Subramanian and Fransisco Trebbi. 2004. "Institutions Rule: The Primacy of Institutions over Geography and Integration in Explaining Economic Growth." Journal of Economic Growth, 9(2), 131-65.

Vivalt, Eva. 2015. "How Much Can We Generalize from Impact Evaluations?" http://evavivalt.com/wp-content/uploads/How-Much-Can-We-Generalize.pdf. 